\title{
WestVirginiaUniversity
}

THE RESEARCH REPOSITORY @ WVU

Graduate Theses, Dissertations, and Problem Reports

2000

\section{Training the intuition}

Paul M. Linhares

West Virginia University

Follow this and additional works at: https://researchrepository.wvu.edu/etd

\section{Recommended Citation}

Linhares, Paul M., "Training the intuition" (2000). Graduate Theses, Dissertations, and Problem Reports.

1021.

https://researchrepository.wvu.edu/etd/1021

This Thesis is protected by copyright and/or related rights. It has been brought to you by the The Research Repository @ WVU with permission from the rights-holder(s). You are free to use this Thesis in any way that is permitted by the copyright and related rights legislation that applies to your use. For other uses you must obtain permission from the rights-holder(s) directly, unless additional rights are indicated by a Creative Commons license in the record and/ or on the work itself. This Thesis has been accepted for inclusion in WVU Graduate Theses, Dissertations, and Problem Reports collection by an authorized administrator of The Research Repository @ WVU. For more information, please contact researchrepository@mail.wvu.edu. 
Training the Intuition

Paul M. Linhares

\begin{abstract}
Thesis submitted to the
College of Creative Arts at West Virginia University in partial fulfillment of the requirements for the degree of
\end{abstract}
Master of Fine Art in Ceramics

Bob Anderson, Chair

Paul Krainak

Sarah Smelser

Janet Snyder

Division of Art

\title{
Morgantown, West Virginia 2000
}

Keywords: Ceramics, Pottery, Functional Pottery, Craft, Craftsmanship, Teapot, Bowl, Gravity, Intuition 


\section{ABSTRACT \\ Training the Intuition}

\section{Paul M. Linhares}

This thesis is about the ceramic art of Paul Linhares. It deals with his many aesthetic theories about the form and function of of his pottery. The thesis includes sections on motive, personal influences, descriptions of the pots themselves, white wood fire clay bodies, and images of some of the works included in Paul's thesis exhibition. 


\section{TABLE OF CONTENTS}

Introduction to Motive............................................................................................1

Importance of Inclusion.................................................................................................1-3

Influence..............................................................................................................................3-4

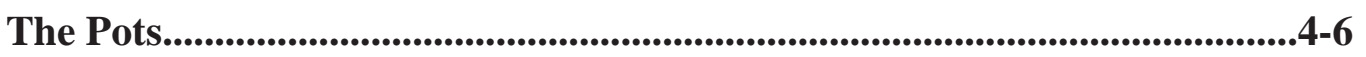

The Surface..........................................................................................................6-7

White Wood Flashing Clays...............................................................................................7-9

Conclusion............................................................................................................................9

Images...................................................................................................................................10-12

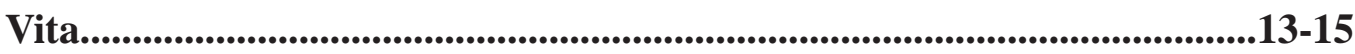




\section{INTRODUCTION TO MOTIVE}

Someone once told me that becoming a potter was a process of training the intuition. The longer I work in clay the more I believe this to be true. Understanding the nature of clays, formulating glazes, manipulating the clay to shape, handling the material in its various stages and controlling the different types of firings are just techniques that must be internalized for truly extraordinary expressions to take place. My intuition filters everything I come in contact with and turns it out as a statement that reflects my perspective at a given point in time. All the different things I have seen, or read, or imagined are brought to bear upon an object. The intuition invites magic and creates a possibility for transcendence by adding elements of surprise and playfulness that bring life to a piece. Through it I attempt to create works that appear to have been born rather than simply made, ones that possess a vitality beyond what I am capable of consciously giving them. I am not trying to say that I whip work out unconsciously, on the contrary, I think about and exercise a great deal of control over the whole process of creating a pot. It is enough control to make a "decent" pot most of the time, but the really good ones come out when the control is compromised and the intuition is allowed to explore the possibilities.

Pottery is a visual, tactile, interactive and spiritual medium which is capable of being experienced on many levels by individuals of diverse backgrounds. The relationship of people to pottery is very old and the domestic context of the forms, whether specifically functional or not, make pottery a broadly accessible art form. I feel this accessibility validates anyone's reaction to my work regardless of their background. There is a danger that any explanation of the meaning or significance of my work in words can limit the potential interpretation or interaction by someone who is experiencing it first hand. Indeed, it is my feeling that the reason human beings still make and value visual art stems from its ability to transcend the rationality of language. It is important to understand this document is a verbalization of the kinds of things I think about when working in clay for the benefit of those who are interested and not a replacement for the participation in meaning that is possible in the experience of the actual work.

\section{IMPORTANCE OF INCLUSION}

Functional pottery is an inclusive art form. The implication of shared meals is one of the things that originally drew me to working in clay. It seemed the ceramics department was always getting together and sharing great food. This connection to food acts to involve people in the work whether or not they are used to having handmade pots during mealtime activities. Part of them wants to know: Will it explode in the microwave? Is the glaze toxic? Will my mother's eggplant casserole fit in there? Will the handle be comfortable? The brain is activated and dreaming up ways the pot could be used: "Oh look, I could put pickled eggs in there!" "What a perfect asparagus baker!" "I can hide money in this thing!" All of these act to draw in and disarm people experiencing the work. 
Another element of inclusion is the emphasis on formal issues of three dimensional composition. Pots dating from the earliest times in far flung locations have a very similar sense of form and balance reminiscent of basket or vegetable forms which are dictated by the gravitational pull of the earth. I feel the consistency of balance and proportion of pottery forms is evidence of a universal, subconscious sense of weight and relationship with gravity that we use when evaluating whether or not a form looks "right". It does not matter if the pot is symmetrical or asymmetrical there is still a feeling of awkwardness if the visual proportion and transitions of the weight are not in tune with this sense. If you took a lump of clay and dropped it from a sufficient height it would smack down into a half-spherical kind of cow patty shape which could demonstrate the clay's relationship to gravity and might prove to be a rather uninteresting viewing experience, but when that same lump is hollowed into a form on the wheel and brought upward in defiance of gravity it creates a narrative of making that engages people in a dialogue. How does the form stand in space? Will it tip over if I brush against it? How much could it contain? Is it light or heavy? The language of gravity breaks down many barriers allowing access to at least one level of the work to anyone who happens upon it.

Craftsmanship or mastery of technique is another facet of my pottery that has broad appeal. We are not really that many generations removed from the days when handcraft practices were essential to our daily existence, and many of us have living family members or have heard stories of family members who were involved in these activities. I just learned my great grandfather, who was responsible for bringing the Linhares to St. Louis, was from a family of luthiers and had adapted the craft to the making of prosthetic limbs, which he made and sold after the Civil War. Even though we live in a mass produced, mechanized world, it is a relatively new phenomenon and many people still feel these kinds of familial ties to hand crafts that manifest themselves as a fascination with the technical aspects of making pots. For example, when I took a graduate seminar class at WVU in the spring of ' 98 the instructor, Andrew Johnson, had the class tackle many pressing issues in contemporary art theory. Our last assignment was to do part two of a presentation on the theoretical aspects of our work, and I decided to do a performance art presentation about my work. I had prepared a formal statement about my theories of beauty and the universal gravitational sense, and attempted to read it to the class while I threw a large bowl and proceeded to fill it with hand thrown light bulb shapes. It was Andrew's custom to jot notes during the presentation in order to formulate questions for the end. I was nervous because I did not see him writing, and before I could finish the questions started: Won't those blow up in the kiln if you don't poke holes in them? How long have you been working on the wheel? Is that porcelain? Are you going to fire those? What kind of glaze are you putting on them? Are they going to stay stuck together if you leave them in that bowl? Can you make a floodlight shape? The other issues had become completely secondary to their curiosity, it appeared as if we had forgotten why we were there. I have found this fascination to be quite common even among other potters. The process of ceramics is still mystical and complex; it inspires a curiosity that further draws people into the work. 
So what? What good are all these ubiquitous lures? I think people have a sense when they interact with pots that it is a thing people all over the world can relate to; this sense reminds us of the things we have in common. It is an ancient art that goes back to the roots of humanity. The direct involvement or implied involvement of pots in the sharing of food, for me, illustrates our potential to be good to each other and endure into the future. Inclusiveness acts as an invitation for people other than the artist to create meaning and to participate in a physical way with the work. I want to spark peoples' imagination with different ideas of use and get them involved through the many levels of accessibility in the hope that they might see their ideas as a valid part of my art. This kind of invitation coupled with an "in tune" sense of form can create a feeling of beauty that is uplifting. I know this all sounds a little Pollyanna, and maybe it is, but I do not think it is outside the range of possibility and it certainly is my intent when I sit down to make a pot to employ these somewhat universal principles in a manner that will engage a wide range of people. This participation in a feeling of beauty and reminder of things we have in common can empower people in their daily lives. Sometimes, I like to think about it while I'm making pots.

\section{INFLUENCE}

My work is in a constant state of evolution with no real starting point or ending point. To stop in the middle and make observations is a valuable but annoying exercise; it feels like an attempt to nail down what is constantly moving and can not be nailed down. However, such a pause always reveals aspects of the work that were unrealized. Generally, I have a list of things I would like to see in my work that manifest themselves in differing orders of importance from series to series or even piece to piece. These are the things I have been talking about like a feeling of beauty, an invitation to participation, function in a utilitarian sense, a feeling of fun or optimism, playfulness or whimsy, technical exploration, reference to tradition, and a feeling of being new or fresh. I want my work to be seen by other potters as "good pots". Some would say it is a matter of fashion or taste, but I think there is a living tradition of pottery form that dates back to the earliest times and is based in the sense of rightness that I talked about before. This is not to say pots made today are employing exactly the same criteria as the ones made thousands of years ago, just that some of the same criteria survive today. The difference between working in a tradition and working in a living tradition is in the first you are using all of the old established rules, as in historical reproduction ware, while in the latter you shed some of the old rules and with your contemporaries create a new structure by consensus. I am influenced by established artists like Pete Pinnell, Chris Staley, Suzi Lindsy, Mark Shapiro, Clary Illian, and countless others. My pots borrow from historical sources like Sung Dynasty porcelain, Minoan Bronze Age wares, PreColombian terracottas, neolithic Iranian, and many more that I do not even consciously realize. These sources, old and new, are not as strong as the influence of the potters and teachers I have met and worked with in undergraduate, professional production, and graduate studies. Personalities and day to day interaction with others has always fed my work in the most significant ways. I am the sponge and the filter for all these things and when they manifest themselves in my 
work I do not shy away from them for fear of losing my originality, but I embrace them as a reminder of a living tradition being projected by a whole community of contemporary potters. I do think about my current work in relation to these influences, but I try not to dwell on them and just do what comes naturally.

\section{THE POTS}

I make a lot of hand-sized bowls. For me, even though I think they look good, these bowls are much more about use than being a strong aesthetic statement. Because they look like they might fit well in the hand, people are compelled to pick them up and then the sense of touch bypasses the logic circuits and they start thinking about pumpkin soup or something. For some time now I have been trying to resolve the display-preciousness-use triangle that I perceive inhibits the potential expression or statement of these bowls and other small domestic forms like mugs. Quite often in people's homes fine handmade bowls end up on a shelf and in the case of gallery display, literally, up on a pedestal. The sense of touch, which is very important in the full appreciation of these objects, is rarely employed. I would like to see these pots fully belong in a gallery as striking aesthetic objects and still present a compelling invitation to be handled. It would be better still if they were filled with soup and someone had to put their lips on them to get at the last bits of broth. Then a bowl has truly lived. My latest attempt to close this circle involves presenting them in groups, because one bowl can sit on a shelf and be unheard, but eight bowls crying out together beckon engagement. In order to strike a balance between presentation and utility some of them rest in wooden boxes which hang on the wall. They lend these bowls a presence they would not have in the cupboard and enhance the invitation to use with easy access. People could choose not to touch or eat from these bowls and just appreciate them as a visual statement, but I would feel negligent in my role as a potter if I did not make my best attempt at inviting them to touch and eat.

Another form that begs to function is the teapot, although my teapots turn the tables on the bowls and function primarily as aesthetic objects. I am not sure why that is, one guess is that the teapot is a more complex form of three dimensional composition that challenges me to balance its awkward appendages in a way the bowl can not. Many contemporary potters have decided that the visual challenge is enough and they work with the teapot in a sculptural way with no consideration for the pouring and drinking of tea. My teapots, as I said, are mainly aesthetic, but I do take great care to see that they function properly by sharpening just the tip of the spout to prevent dripping, placing the spout on the lower portion of the pot where the stronger tea will steep, and providing a flange on the lid so it is not likely to fall off when pouring the last bits of tea. I do not expect the majority of people who have my teapots will use them, but I want them to be pleasantly surprised if they do.

Visually these teapots are reminiscent of Yi Xing ware, but the size and spout placement 
lend them a western flavor. The process of constructing one of my squared teapots can dictate many of the subtle relationships between the various parts. The body is thrown in two parts: a bottom that is squared on the wheel, and a top that is flat and fits the lid. The swelling of the base form sets the basic curve of the pot but it is altered when it is squared and then again when the corners are added as coils after the clay sets up. It is difficult to determine whether the final form will look good while throwing, especially if the body is to be ovaled or rectangled. Most of the time I just go with it when making the body and try to resolve the piece with the knob, handle and spout. The handles are most often over the top because it creates a wonderful negative space around the shape of the knob. Constructed from a flat coil of clay that is tapered in the middle, the handle is slapped flat on a table and ribbed into a smooth shape. The spout evolved from a Yi Xing pottery demonstration I saw at WVU, where I was exposed to several new hand building techniques including rolling spouts from a solid cone of clay. Starting with a cone of clay, proportioned to the size spout desired, a tool (I use a long tapering oil paintbrush handle) is inserted in the fat end of the cone and worked down to the tip while rolling the cone on the table. My spout at this stage is rather thick and clumsy but then I take it and smack it in a horizontal downward motion, turning it a quarter turn with each successive smack until I have a squared, more tapered spout that I can rib smooth. The knob is where the real art happens. Being framed by the handle and set on top of the pot, the knob sets the tone for the whole personality of the piece. It could be whimsical or straight forward, it could mimic the shape of the pot or come out of left field, daring the viewer to question its existence. I have fun with knobs and occasionally inflate their importance to a pot for the chance to jump start someone's imagination. As a group, the contrasts among the squared teapots may seem too small and reflect too rigid a framework for self expression, but I am compelled to use the process as a rudder for exploring this series and let the progress unfold at its own pace.

The work that has most separated itself from food related function, I have been calling "tall skinny pots," because all I knew about them when I thought to make them was that they would be tall and skinny. I had a clue that they would be pots with lids or maybe vases, because making tall skinny ewers seemed like just one too many spouts in the studio. As I began the series I tried to make pots that were organic and anthropomorphic, more like caricatures of jars than actual jars. On some of them the knobs and handles referenced natural objects like leaves, smoke and logs, while the bodies resembled internal organs or the skins of genetically manipulated vegetables caught in the act of performing some kind of belly dance. Then I started making a smooth-sided, square version reminiscent of my teapots being stretched and twisted into a dancing skyscraper. The architectural parallel contrasted by the undulating figurative curves of the wheel throwing process produces an alluring effect. These pots are the most intuitive yet, I am trying not to make decisions about them outside of the making process. Rather, I am working and reworking them until the whole thing feels right or I just feel finished. Sometimes I leave things I do not like and return to them the next day to see if the feeling is still the same, or just work with the other elements on the pot to reconcile the awkward element. I do not think these pieces are particularly 
stronger than some of the food-functioning work, just different. I suppose they might be seen as being stronger because they are visually more aggressive; they demand more attention when someone first sees them as opposed to the time it takes to get to know a bowl through daily use. It is not a question of strength, just difference.

\section{THE SURFACE}

The ceramic surface is in contrast to the form in many ways. A busy surface with figures, patterns or lines can distract the eye from the form and in some cases make the form irrelevant. During the process the form is finished in the wet clay, a manifestation of the smooth, squishy, sensuous earth; and the surface is finished in the unforgiving, chaotic trial of the fire. The type of manual dexterity required to manipulate the clay is of little use in the kiln. What is needed here is more like scientific dexterity, and not the science with slide rulers and number crunching mainframe computers, but science like old science of keen observation, note-keeping, and trial and error experimentation. It is a different kind of mental process and can manifest itself in pots that are disparate in form and surface. They are separated by time in the processes of drying and bisque firing, which increases the difficulty of creating a harmonious relationship. Currently, I see myself as having stronger forms than surfaces and I often find myself liking a piece much more before the firing than after, but there is no denying the fire is magic and quite often produces results of uncompromising and unrepeatable beauty. It has taken a much longer time for me to begin to internalize the complex relationships between the myriad of ceramic materials available to me as a potter in the twenty-first century. By making choices to limit the number of materials I use most often, I have been able to develop a rudimentary intuitive sense of what combinations might work under different circumstances.

The surface effects of flame on the pot flow around the form and are interrupted by it, the marks left by wood firing have a way of uniting the form and surface. I have spent a lot of time trying to master and internalize the techniques of ceramics, but I can not get over the desire to have the process continually refresh me, to see a miracle everyday. The idea of gaining control of what can not be controlled is one of the things that keeps ceramics interesting to me. It would be possible at this time for me to find a process; clay, glaze and firing combination; that I could achieve predicable results from and could then go about using the elements of form, color and composition to create work of imagination and interest, but in a way it would be dead to me. The wood kiln is a way of heaping variables upon variables, to invite the magic of quantum physics and chaos theory, to literally reenact the forces that are still creating the universe, to invite death and disaster to dinner and occasionally come out on top. When firing kilns there is always talk of atmosphere: reduction, a condition of having extra fuel or carbon; oxidation, a condition of having excess oxygen in the kiln; and neutral, a balance of oxidation and reduction. Metallic oxides in clays and glazes react with the atmosphere with parts of them being coaxed into one kind of a 
molecular bond or another with the excess carbon or oxygen creating, often times, a wide range of characteristic differences in color and melting power. When a piece of wood is thrown into the firebox of a hot kiln it nearly explodes into flame, releasing a stream of superheated gasses, including a ton of carbon and some of the same alkaline materials found in glazes. The stream is divided at the inlet flue as it enters the kiln chamber, it is forced upward by the heat and the bagwall before it can turn towards the pots and snake down through the shelves, out the exit flue, past the damper, and up the stack. Between these carbonaceous streams, the kiln atmosphere can remain clear and oxygenated. This is the dynamic, ever-changing atmosphere of a wood kiln. It is at once oxidized and heavily reduced, creating an unimaginable variety of effects on the surface of raw clays and oftentimes confounding any attempt to repeat a glaze surface. Working with clay and glazes in a wood kiln is not often a willful art; it is more like a partnership between myself and the kiln.

I have tried in my technical investigations to be aware of the expertise in books and of my peers, but I rely and act on results from the kiln. It is a very real possibility that my interpretations of the results or assumptions based on those results are very wrong. This is a gray science and potters should always have a healthy skepticism about using each others' methods.

\section{WHITE WOOD FLASHING CLAYS}

I fell in love with the atmospheric action of the wood and salt firing during my second semester of graduate school; the orange blushing of the clay, the occasional over-fluxing of the glazes, and the mixture of oxidation and reduction effects on the same pot drew me in to the process.

I reveled in the randomness but I wanted to understand it more. Even though I experimented with many glazes and firing techniques my major research in school has been to develop a clay body that takes advantage of the wood and salt firing.

My observation of kiln results has led me to believe that flashing, or orange blushing, of the clay body is a reaction between the kiln atmosphere and the clay.

For example:

- A Grolleg porcelain body will flash more in the areas of the kiln that are more reduced.

- Bodies that are relatively high in alumina and soda flash brighter.

- Bodies that mature faster and end up very tight will develop deeper color.

- Trace iron content can aid flashing in a more oxidized atmosphere.

- A little bit of salt can go a long way.

Here is a list of clay body materials that I work with and a short description of why I choose that material.

Kaolex is a relatively non-plastic kaolin that is high in alumina and we had a large supply of it on the loading dock that no one was using. 
Tennessee \#10 is a ball clay that is much whiter than many others.

XX Sager is a ball clay that I heard encouraged flashing, but I never found that to be particularly true.

6 Tile is a kaolin which I found to be much more plastic than Kaolex.

B-Mix5 Is a cone five commercial clay made by Laguna Clay Co. that I had used as a production potter and found to be a sensational throwing body. Originally, I used it as part of a cone six body was developing to add throwing capacity and assist in maturing the clay, but now I pretend it is a ball clay when formulating a new body. It can be purchased dry and costs about thirty cents a pound in fifty pound lots.

Old Hickory is a ball clay that contains a higher percentage of iron than most. I particularly like the fact that the iron particles are small and manifest themselves as color instead of the brown specks common in fire clay.

Nepheline Syenite Is a feldspar that I use for my main body flux. It is high in alumina and soda. It fluxes earlier and stronger than typical high fire feldspars.

Pyrax is substituted for part of the silica in order to reduce the formation of crystobolite and increase the bodies resistance to thermal shock.

$\mathbf{3 1 2 4}$ is a Ferro frit that acts as a very strong body flux. I started using it in my clay when I was going to cone six, but I left it in when I saw these highly fluxed bodies coming out of the cone ten wood firings.

Here some of the clays I have worked with during the past three years:

White Stone Cone 10

Tennessee \#10

XX Sagger

Hawthorn Bond 10

6 Tile

G-200 Feldspar

Silica $200 \mathrm{~m}$

White Wood Flashing Cone 10

Tennessee \#10

Old Hickory

Kaolex

Neph Sye

Flint 
Flashing White Cone 10

B-mix 5

Kaolex 30

XX Sagger $\quad 10$

Old Hickory 5

Neph Sye $\quad 15$

Silica 15

Pyrax 4

3124

Triple K White Cone 10

$\begin{array}{lr}\text { B-Mix 5 } & 20 \\ \text { Kaolex } & 15 \\ \text { 6 Tile } & 13 \\ \text { EPK } & 13 \\ \text { Old Hickory } & 2 \\ \text { Neph Sye } & 15 \\ \text { Silica } & 15 \\ \text { Pyrax } & 5 \\ 3124 & 2\end{array}$

\section{CONCLUSION}

I would like my work to be seen and felt by a wide range of people. I want them to come away with a sense of fun and mystery similar to what I feel when working with the material. I hope that my audience gets some of the positive implications about some things people have in common and the sharing food. I need them to take my work and create new meanings and uses for it in their own lives, so that it can have a life of its own and become something bigger and better than the sum of my efforts as a potter. 


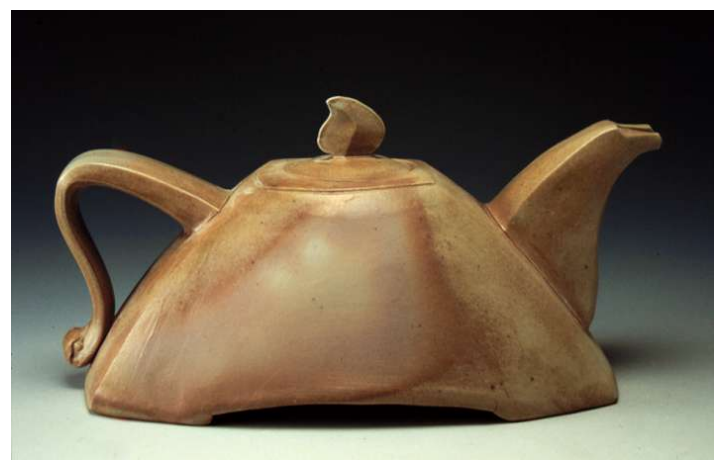

Low Rider Teapot

Salt Fired Stoneware

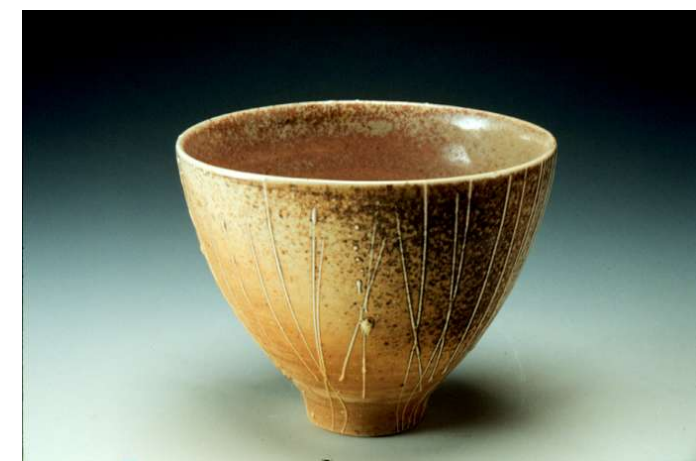

Small Shino Bowl

Wood Fired Stoneware

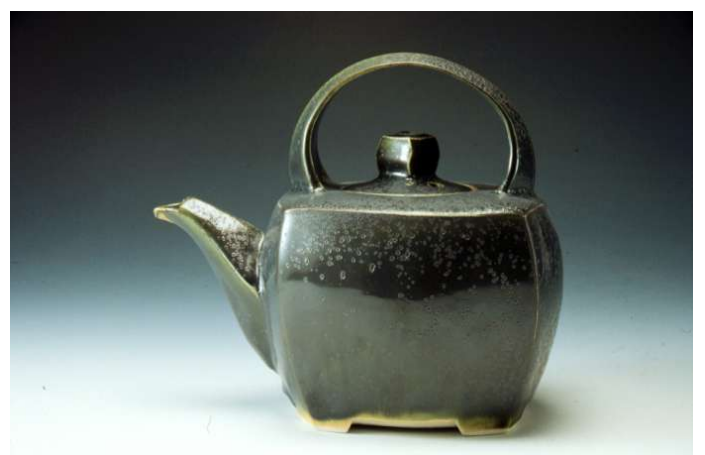

Dark Green Teapot

Wood Fired Porcelain

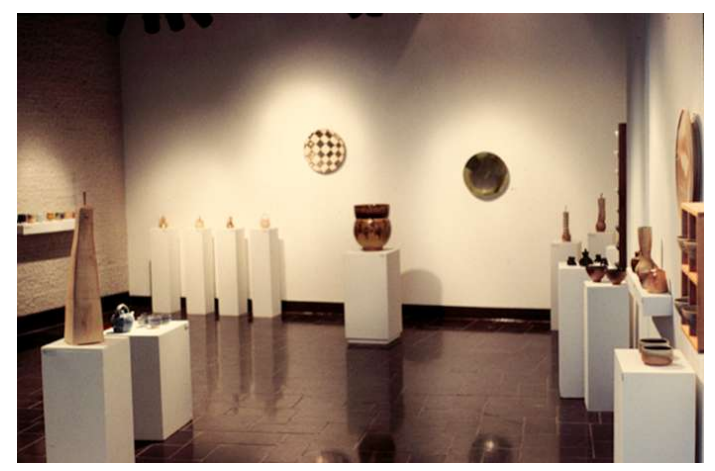

Fresh Pots

Paul Masaros Gallery

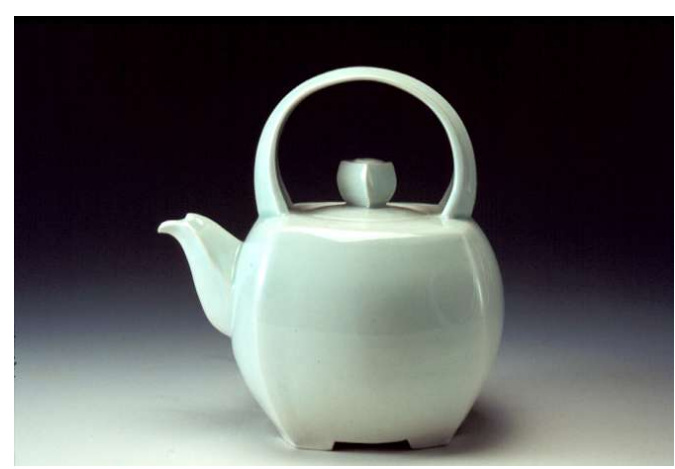

21 Teapot

Reduction Fired Stoneware

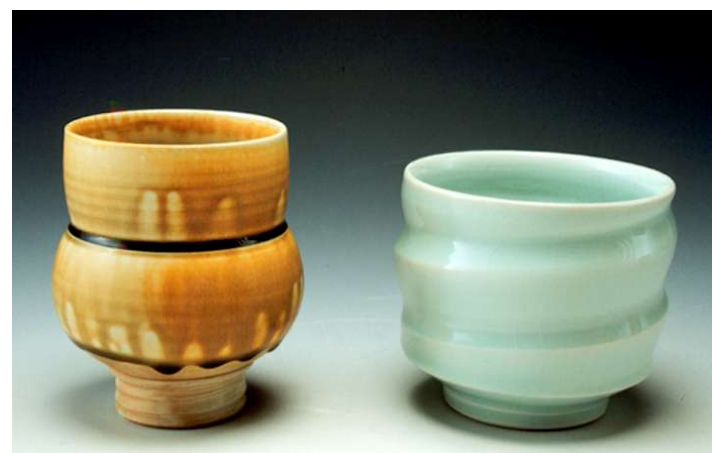

Two Teabowls

Wood and Reduction Fired Stoneware and Porcelain 


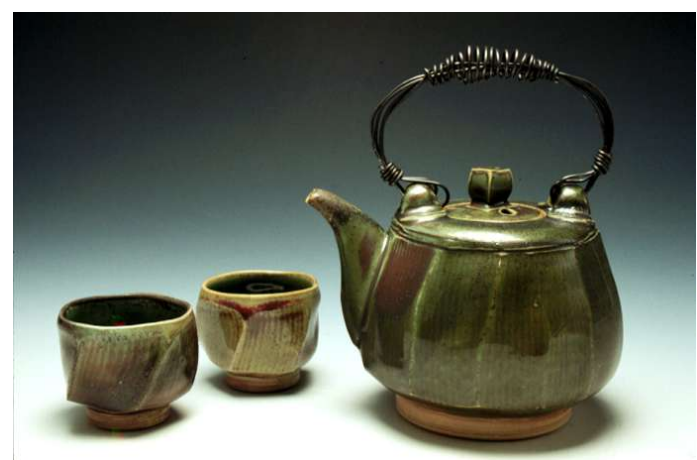

Wire Handle Teapot

Wood Fired Stoneware

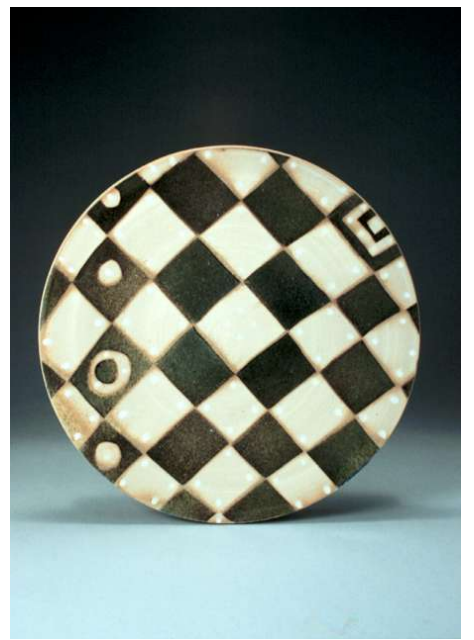

Game Board Platter

Wood Fired Stoneware

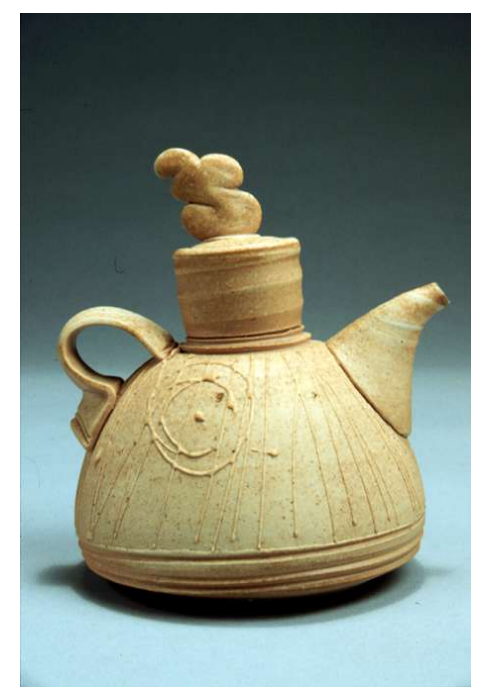

Lil Smoky Ewer

Wood Fired Stoneware

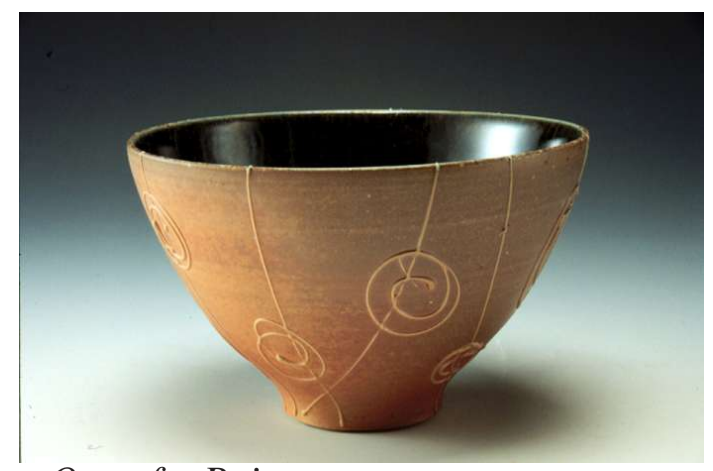

One of a Pair

Wood Fired Stoneware

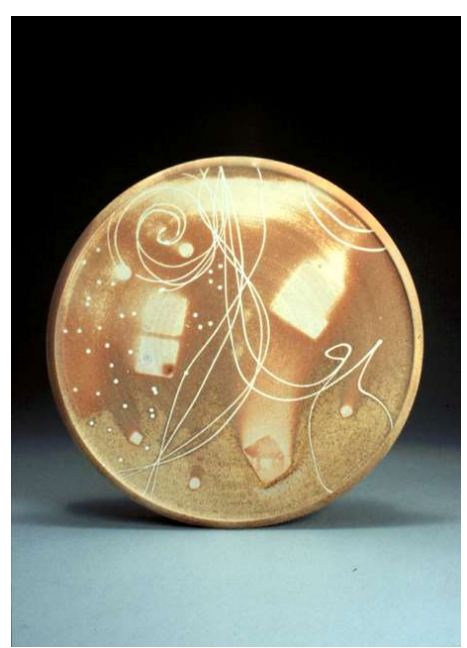

Traces of Atmosphere Wood Fired Stoneware

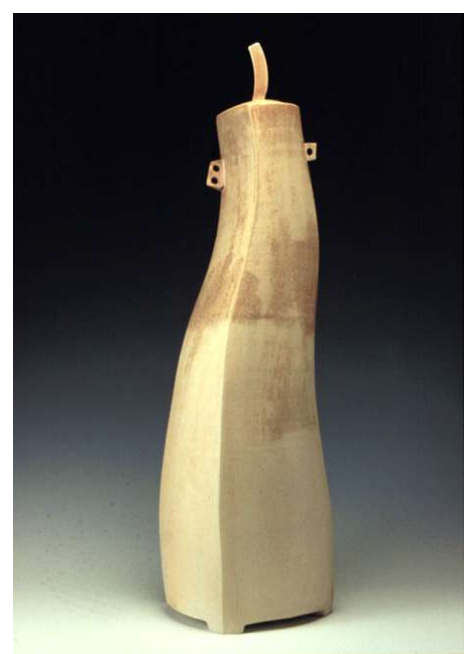

Skin and Concrete

Wood Fired Stoneware 


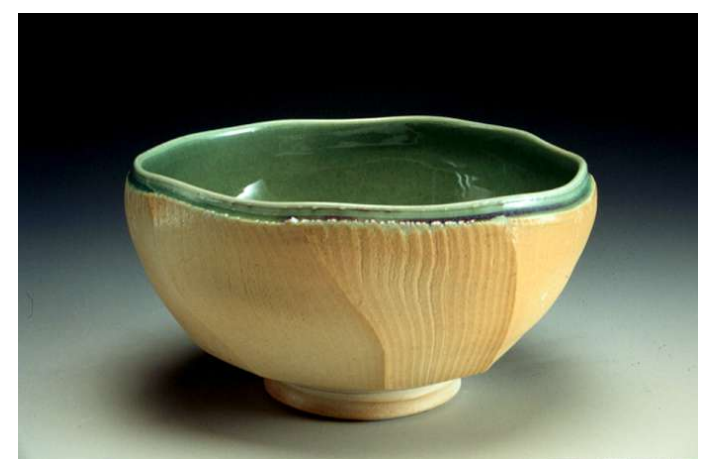

Water Blue Bowl

Wood Fired Porcelain

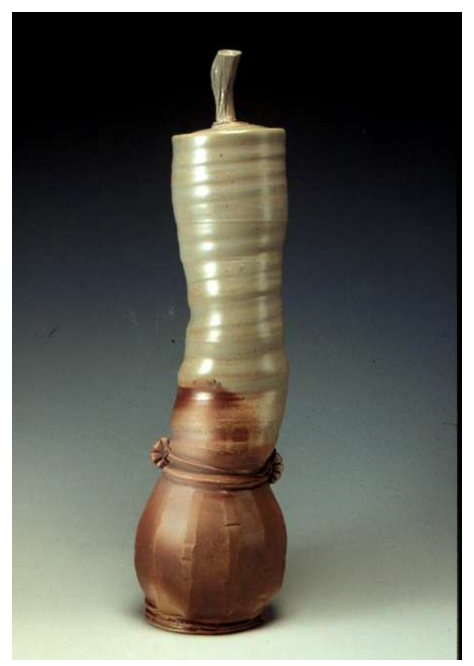

Altered

Salt Fired Stoneware

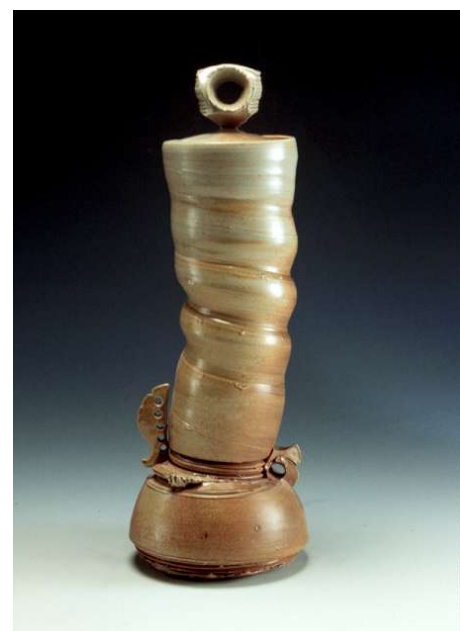

Manipulated

Salt Fired Stoneware

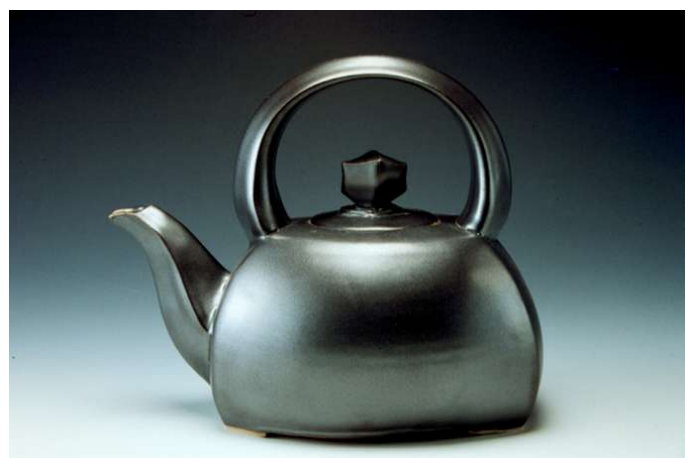

Satin Doll Teapot

Wood Fired Stoneware

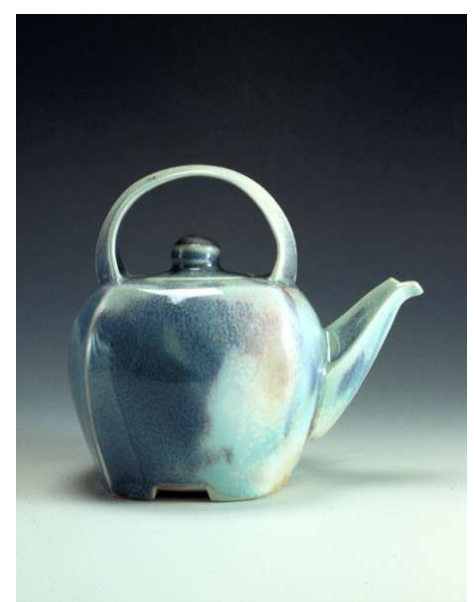

Kinyo Teapot

Wood Fired Porcelain

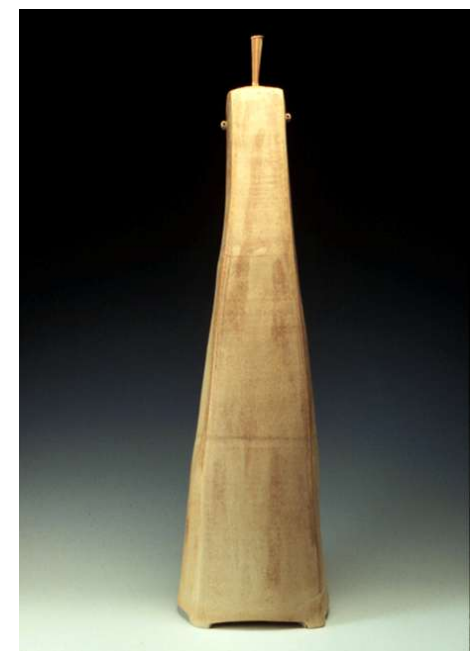

Solitude

Wood Fired Stoneware 


\section{PAUL M. LINHARES}

\section{EDUCATION}

Master of Fine Art, West Virginia University - projected May 2000

Morgantown, West Virginia

Bachelor of Fine Art, Southern Illinois University - May 1991

Carbondale, Illinois

\section{TEACHING EXPERIENCE}

Instructor, Art 140 and Art 141 - Beginning Ceramics for Art Majors

West Virginia University

August 1998 - Present

- Responsible for creating course curriculum and accompanying syllabus

- Conducted projects in hand building and wheel throwing techniques

- Projects finished in wood, salt, pit and stoneware reduction firings

- Researched and developed glaze and other surfaces for finished projects

- Created glaze calculation assignments for second semester students

Instructor, Art 101 - Ceramics for Non Art Majors

West Virginia University January 1998 - May 1998

- Responsible for creating course curriculum and accompanying syllabus

- Conducted projects in hand building and wheel throwing techniques

- Emphasized the relevance of creativity to the students other endeavors

Teaching Assistant, Art 391 - Ceramic Production Methods

West Virginia University

- Organized 200 level students to produce class projects

January 1998 - May 1998

- Relayed production experience by demonstrating how to streamline tasks

- Supervised glazing and firing of final work

\section{RELATED PROFESSIONAL EXPERIENCE}

Sole Proprietor - Mudskipper Pottery

Coshocton, Ohio

Production Potter and Glaze Technician - Millcreek Stoneware

Coshocton, Ohio

July 1993 - August 1997

Potter's Apprentice - Jeff Reed and Sarah MacFarland

Colorado Springs, Colorado

November 1993 - August 1997

Production Potter - Three Rivers Pottery

Coshocton, Ohio

March 1993 - July 1993

Class Instructor and Clay Shop Technician - the Student Center Craft Shop

Carbondale, Illinois

July 1990 - May 1991

\section{SOLO EXHIBITIONS}

Fresh Pots, Mesaros Gallery, West Virginia University, Morgantown, West Virginia, April 2000

Recent Works, Zen Clay, Morgantown, West Virginia, July 1999 


\section{JURIED EXHIBITIONS}

Utilitarian Ceramics National, Nicholls State University, Thibodaux, Lousiania, April 2000

Continuing the Search, Mesaros Gallery, West Virginia University, Morgantown, West Virginia, May 1999

NCECA Regional Student Juried Exhibition, Fort Hays Metropolitan Arts Center, Shot Tower Gallery, Columbus, Ohio, February 1999

Formal Tease, Mesaros Gallery, West Virginia University, Morgantown, West Virginia, May 1998

International Orton Cone Box Show, Baker University, Baldwin City, Kansas, March 1994, work included in the traveling exhibition

Studio Artist Show, Manitou Gallery, Business of Art Center, Colorado Springs, Colorado, August 1993

Atrium Gallery Show, Atrium Gallery, Business of Art Center, Colorado Springs , Colorado, May 1993

Sculpture In Your Outer Space, Southern Illinois University, Carbondale, Illinois April 1991

Student Center Purchase Award Show, Student Center, Southern Illinois University, Carbondale, Illinois, March 1991

Rickert-Ziebolt Trust Award Show, Allen Hall, Southern Illinois University, Carbondale, Illinois, March 1991

Southern Illinois Pottery Past and Present, John A Logan College, Carbondale, Illinois, October 1990

\section{HONORS AND AWARDS}

Purchase Award, Utilitarian Ceramics National, Nicholls State University, Thibodaux, Lousiania, April 2000

Graduate Teaching Assistantship, Tuition and Stipend, West Virginia University, Morgantown, West Virginia, August 1997 - May 2000

Permanent Collection Purchase, Pomerene Fine Art Center, Coshocton, Ohio, January 1996

Second Place Award, Findlay Area Arts Festival, Findlay, Ohio, June 1995

Best of Show in Clay, Springfield Art in the Park, Springfield, Ohio, June 1994

Pacer Corporation Purchase Award, International Orton Cone Box Show, Baker University, Baldwin City, Kansas, March 1994

Honorable Mention Award, Sculpture In Your Outer Space, Southern Illinois University, Carbondale, Illinois April 1991 
Talent Scholarship Award, Southern Illinois University, Carbondale, Illinois, November 1990

\section{PUBLICATIONS}

The Dominion Post, "Guatemalan coffee gift to community," December 5, 1999

The Coshocton Tribune, "Affordable Art," December 7, 1995

Ceramics Monthly, "International Orton Cone Box Show", January 1995, p. 29

\section{PROFESSIONAL ACTIVITIES}

Workshops

Visiting Artist Demonstrations, The Craft Shop, Braxton Towers, West Virginia

University, Morgantown, West Virginia, April 1999

Artists' Panel Discussion, NCECA Regional Student Juried Exhibition, Fort Hays Metropolitan Arts Center, Columbus, Ohio, March 1999

Visiting Artist Demonstrations, Meramec Community College, St. Louis, Missouri, May 1995

Visiting Artist Demonstrations, Meramec Community College, St. Louis, Missouri, October 1993

Conferences

National Ceramics Education Conference of America (NCECA), Columbus, Ohio, 1999

NCECA, Las Vegas, Nevada, 1997

NCECA, New Orleans, Louisiana, 1994

NCECA, Philadelphia, Pennsylvania, 1992 